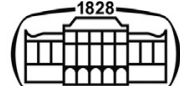

AKADÉMIAI KIADÓ

Central European

\section{Geology}

$63(2020) 1,19-26$

DOI:

$10.1556 / 24.2020 .00001$

(c) 2020 The Author(s)

\title{
New Late Cretaceous (Coniacian) sauropod tracks from Hvar Island, Croatia
}

\author{
PÉTER SOLT ${ }^{1}$, ANDREA SZUROMI-KORECZ $^{2}$ and \\ ATTILA ÖSI ${ }^{3,4 *}$ \\ ${ }^{1}$ Mining and Geological Survey of Hungary, Budapest, Hungary \\ ${ }^{2}$ E\&P Laboratory, MOL Plc., Budapest, Hungary \\ ${ }^{3}$ Department of Paleontology, Eötvös University, Budapest, Hungary \\ ${ }^{4}$ Hungarian Natural History Museum, Budapest, Hungary
}

Received: June 28, 2019 • Accepted: November 6, 2019

Published online: August 27, 2020

\section{ORIGINAL ARTICLE

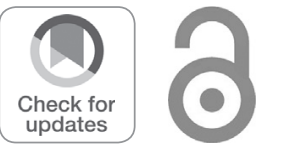

\begin{abstract}
In June 2017 a new sauropod trackway locality was discovered in the central part of the AdriaticDinaric Carbonate Platform (ADCP), on the island of Hvar (Croatia). The track site is situated on the northern shore of the western edge (Pelegrin) of the island in the upper Turonian - lower Coniacian limestone series. The track site contains altogether 13 footprints arranged in four possible trackways. The largest footprints have a diameter up to $80 \mathrm{~cm}$. In some places the limestone surface is strongly karstified and the tracks are partly eroded, which has certainly modified the original shape and size of the footprints. Microfossil assemblage from the track-bearing beds suggest an early Coniacian age for the tracks. The new trackways on Hvar Island further strengthen the earlier hypothesis that sauropods were present in the western Tethyan archipelago during the late Cenomanian-late Campanian period. In addition, the new tracks, together with those from the Žukova Cove of Hvar, represent two, possibly slightly different stratigraphic horizons close to the Turonian-Coniacian boundary, and suggest that the occurrence of sauropods on the ADCP and possibly also on other parts of the Apulian microplate was not accidental, but rather periodical and more frequent than previously thought.
\end{abstract}

\section{KEYWORDS}

sauropoda, trackways, micropaleontology, turonian-coniacian, ADCP, hvar, croatia

\section{INTRODUCTION}

Although the Adriatic-Dinaric Carbonate Platform (ADCP) was a critical area in terms of Cretaceous faunal interchanges of the western Tethyan archipelago (Dalla Vecchia 2002; Pereda-Suberbiola 2009; Csiki-Sava et al. 2015), dinosaur fossils (or those of other continental vertebrates) from this region are poorly known. As far as body fossils are concerned, significant dinosaur remains are known from Hauterivian-Barremian sediments lying a few meters below the Adriatic Sea level, close to Bale (Vale) in Istria (Boscarolli et al. 1993; Kozarić et al. 1996; Dalla Vecchia, 1998a, 2001; Boscarolli and Dalla Vecchia 1999). Complete and partial skeletons of the derived hadrosauroid Tethyshadros insularis are known from the Campano-Maastrichtian beds of the Trieste region (Dalla Vecchia 2009). In addition, fissure-filling Campanian sediments discovered Paleontology, Eötvös University, Pázmány Péter sétány 1/C, H-1117, Budapest, Hungary.

E-mail: hungaros@gmail.com. in various places of Slovenia provided isolated teeth and bones of different continental vertebrates (Debeljak et al. 1999).

Most of the dinosaur fossils from the ADCP are footprints preserved in various shallow marine, Cretaceous horizons (see e.g., Dalla Vecchia and Tarlao 1995, 2001; Kozarić et al. 1996; Mezga and Bajraktarevic 1999). For a long time, footprints were found only in the northern part of the ADCP, in Istria (Brioni, Cervar, Fazana, Fenoliga, Grakalovac, Kolone, 
Lovrecica, Mirna, Puntesella; see e.g., Kozarić et al. 1996; Dalla Vecchia 1998b, 2001; Mauko and Florjančič 2003; Mezga et al. 2006a).

In 2005 trackways of medium to large-sized sauropod dinosaurs were discovered in the central part of the ADCP, on Hvar Island at Žukova Cove, Dalmatia (Mezga et al. 2006b), in an upper Turonian - lower Coniacian limestone series. These footprints were among the first two sauropod records from the Cenomanian-late Campanian European "Sauropod hiatus" (Nicosia et al. 1999; Mannion and Upchurch 2011), suggesting that this group of herbivorous dinosaurs did not become extinct in the European archipelago but still survived on some islands (Ősi et al. 2017).

In this work we describe a new locality with sauropod dinosaur tracks from Hvar Island that represents another stratigraphic horizon with sauropod occurrence within the so-called European "Sauropod hiatus."

\section{LOCALITY}

In June 2017 a new locality with dinosaur footprints and trackways was found in a Cretaceous limestone series in the northwestern part (Pelegrin) of Hvar Island (Fig. 1). The new site (Fig. 2) is approximately $15 \mathrm{~km}$ westward of the Žukova Cove, from where Mezga et al. (2006b) described the first dinosaur footprints of the island.

Leaving the northern shore of Floriana Bay to the west, we follow the stair step-like Upper Cretaceous limestonebeds (Gušić and Jelaska 1990; Jerinić et al. 1994; Fio Firi et al. 2017) on the rocky seaside. Walking ca. $2 \mathrm{~km}$ along the shore and passing the little islet of Otočić Duga, we reach the new track site (GPS coordinates: N 43 11' 40", E $\left.16^{\circ} 24^{\prime} 04^{\prime \prime}\right)$. On the $870 \mathrm{~m}^{2}$ track-bearing surface, probably four trackways are present, altogether with 13 footprints.

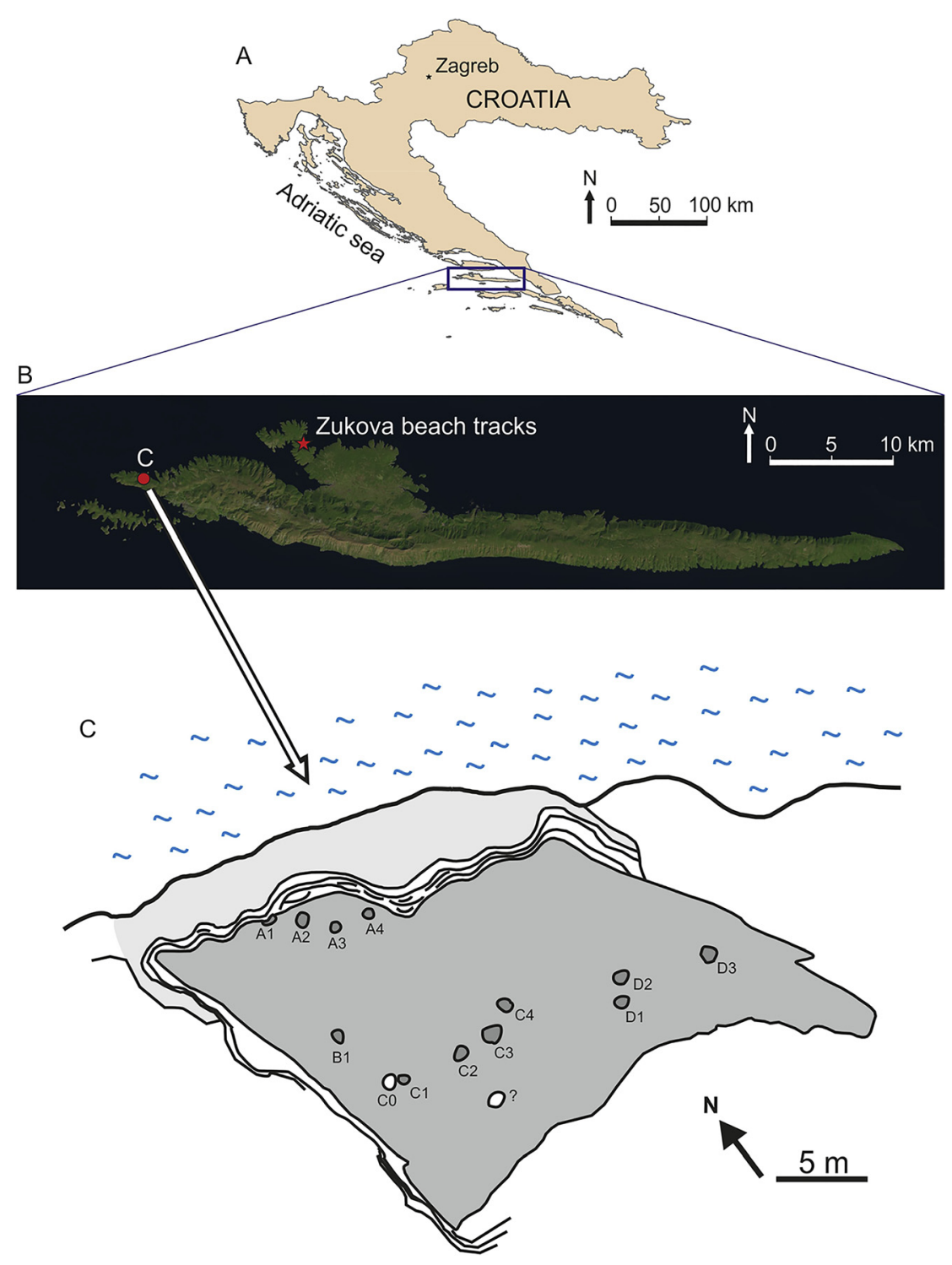

Fig. 1. Location of the new Late Cretaceous track site on Hvar Island, Croatia. A, Position of Hvar Island in Croatia. B, The position of the track site on Hvar Island. C, Schematic explanatory drawing of the track site. Labeled circles are tracks 

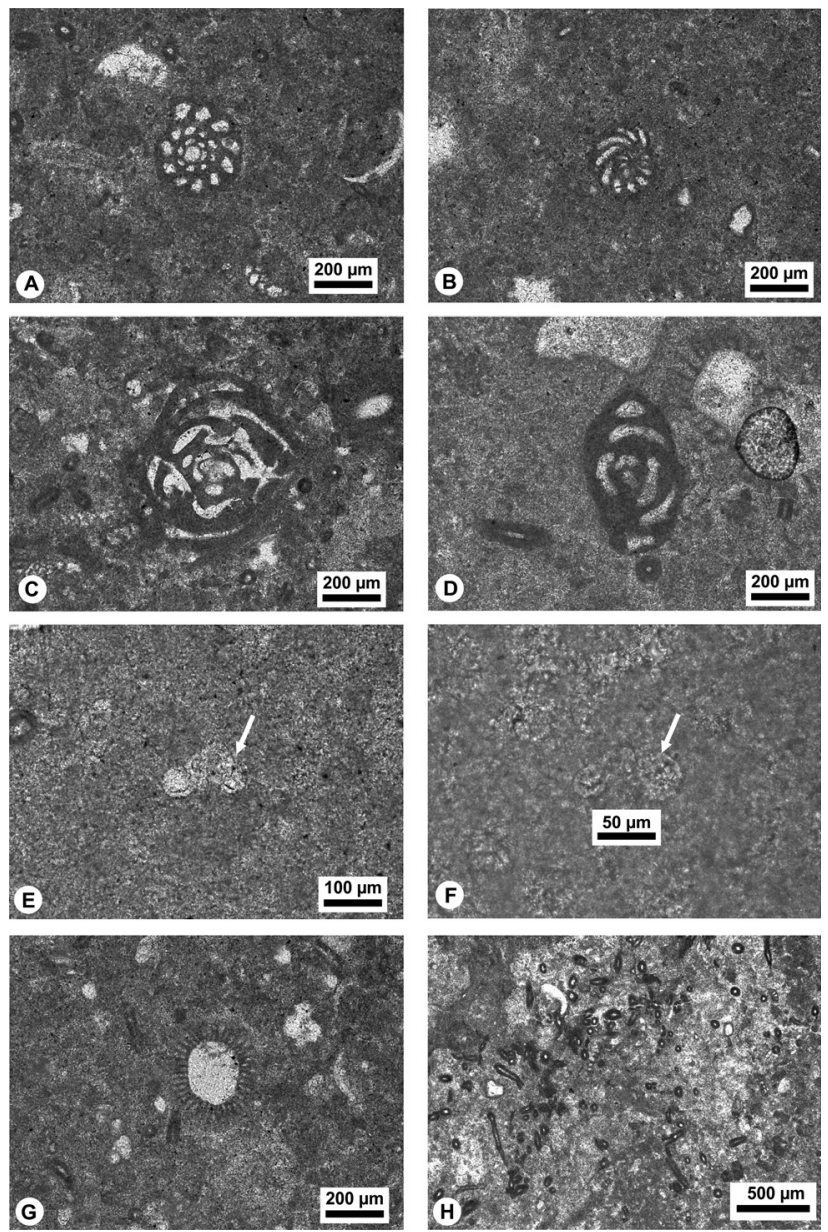

Fig. 2. Some representative elements of the microfossil assemblage from the track-bearing beds. A, Moncharmontia apenninica from sample II-1. B, Pseudocyclammina sphaeroidea from sample II-1. C, Scandonea samnitica from sample II-1. D, Pseudonummuloculina heimi from sample II-2. E, Whiteinella paradubia from sample II-1. F, Hedbergella delrioensis from sample II-1. G, Thaumatoporella parvovesiculifera from sample II-1. H, Aeolisaccus kotori from sample II-1

\section{GEOLOGIC SETTING AND AGE}

The general geology of Hvar Island has been well summarized by Mezga et al. (2006b) when describing the first sauropod trackways from the island. Since the new discoveries described in this paper are from the same region, following a brief general geologic summary we prefer to focus on the sedimentology and micropaleontology of the new track-bearing bed.

\section{General geological background}

Hvar Island belongs to the Dalmatian part of the ADCP. The central part of the island is built up by Lower Cretaceous shallow-marine limestone and dolomite (Marinčić and Majcen 1968). On the hillslopes, in every direction toward the coast, Cenomanian-Turonian laminated limestone and thin-laminated deep-water limestone are exposed (Fio Firi et al. 2017). According to previous work (Fio Firi et al. 2017 and references therein) the new track site, situated along the northwestern coast of the island (Pelegrin Peninsula), is built up by an Upper Cretaceous (Turonian and Senonian) bedded and laminated limestone series (Marinčić and Majcen 1968; Mezga et al. 2006b; Diedrich et al. 2011; Fio Firi et al. 2017).

\section{Sampling for microfossils}

We carefully collected a single sample from each of the three layers (samples II-1-II-3) from the locality for sedimentological, micropaleontological and palynological analyses. The lowermost, massive, $50 \mathrm{~cm}$-thick light-brownish limestone bed (II-1) is overlain by a $10 \mathrm{~cm}$, light-brown limestone bed (II-2) that contains the tracks on its surface. This track-bearing layer is covered by a $20 \mathrm{~cm}$-thick lightbrownish, laminated limestone (II-3). The three rock layers are made up of bioclastic wackestone-packstone, and lamination is present in all the samples (samples II-1, II-2, II-3), but bioturbation can be observed only in sample II-3. The rock samples from the three different layers represent periodically changed environments of the shallow lagoonal or peritidal zone, as observed by Diedrich $(2005,2010)$ at other dinosaur mega-track sites on the ADCP.

\section{Microfossils and age}

Large $(5 \times 5 \mathrm{~cm})$ thin sections were made from the three rock samples collected from the locality. Unfortunately, no detectable palynological remains have been found (SieglFarkas 2018), as it was the case with earlier palynological samplings made close to our site in Hvar by Fio Firi et al. (2017). Other microfossils, however, were present in the samples (for the complete list see Table 1).

In all samples, the green algae Thaumatoporella parvovesiculifera (Fig. 2G) and cyanobacteria Aeolisaccus kotori (Fig. $2 \mathrm{H}$ ), the marker forms for semi-restricted, stressed environments, are present (Tasli et al. 2006; Schlagintweit et al. 2015). Foraminifera assemblages (Fig. 2) are dominated by benthic forms, including many species referring to the euryhaline Miliolidae, which preferred closed lagoons (Davies 1970; Murray 1991). In addition, some members of Textularidae and Buliminidae were also present in the samples. Planktonic foraminifera are far less abundant but some of them - identified at species level - have age relevance. Besides foraminifera, specimens of ostracods and mollusks - including rudist shell fragments originating from the nearby reef environment - are also present in the samples.

The age of the track-bearing bed is definitely Late Cretaceous, as was already concluded for the northwestern coast of the island (Fio Firi et al. 2017 and references therein). The benthic and planktonic foraminifera, however, fortunately provided a more precise age. According to Premoli Silva and Sliter (2002) the temporal range of the planktonic foraminifer Whiteinella paradubia (Fig. 2E) is from the Cenomanian to the early Coniacian, and based on Velič (2007) Scandonea samnitica (Fig. 2C) existed from the 
Table 1. Representatives of the microfossil assemblage from the new Late Cretaceous track site on Hvar Island, Croatia. Table shows that the temporal range of the taxa during the Cretaceous suggest an early Coniacian age for the track-bearing bed (based on Premoli Silva and Sliter, 2002; Velič, 2007)

\begin{tabular}{|c|c|c|c|c|c|c|c|c|c|c|c|c|c|c|c|c|c|c|c|c|}
\hline \multirow{3}{*}{ Samples } & \multirow{3}{*}{ Fossils } & \multirow{3}{*}{$\begin{array}{l}\text { Quantity of } \\
\text { specimen in the } \\
\text { thin section }\end{array}$} & \multicolumn{6}{|c|}{ Early Cretaceous } & \multicolumn{12}{|c|}{ Late Cretaceous } \\
\hline & & & \multicolumn{2}{|c|}{ Barr. } & \multicolumn{2}{|c|}{ Apt. } & \multicolumn{2}{|c|}{ Alb. } & \multicolumn{2}{|c|}{ Cen. } & \multicolumn{2}{|c|}{ Tu. } & \multicolumn{2}{|c|}{ Con. } & \multicolumn{2}{|c|}{ San. } & \multicolumn{2}{|c|}{ Campan. } & \multicolumn{2}{|c|}{ Maas. } \\
\hline & & & 1 & $\mathbf{u}$ & l & $\mathbf{u}$ & l & $\mathbf{u}$ & I & $\mathbf{u}$ & 1 & $\mathbf{u}$ & l & $\mathbf{u}$ & l & $\mathbf{u}$ & l & $\mathbf{u}$ & I & $\mathbf{u}$ \\
\hline \multirow[t]{14}{*}{ II-1 } & $\begin{array}{l}\text { Thaumatoporella parvovesiculifera (RAINERI } \\
\text { 1922) }\end{array}$ & $<10$ & & & & & & & & & & & & & & & & & & \\
\hline & Aeolisaccus kotori RADOIČIIČ 1959 & $>20$ & & & & & & & & & & & & & & & & & & \\
\hline & Whiteinella paradubia (SIGAL 1952) & $<5$ & & & & & & & & & & & & & & & & & & \\
\hline & Hedbergella delrioensis (CARSEY 1926) & $<5$ & & & & & & & & & & & & & & & & & & \\
\hline & Globigerinelloides bollii PESSAGNO 1967 & $<5$ & & & & & & & & & & & & & & & & & & \\
\hline & Hedbergella $\mathrm{sp}$. & $<5$ & & & & & & & & & & & & & & & & & & \\
\hline & Pseudocyclammina sphaeroidea GENDROT 1968 & $<5$ & & & & & & & & & & & & & & & & & & \\
\hline & Pseudonummuloculina heimi (BONET 1956) & $<5$ & & & & & & & & & & & & & & & & & & \\
\hline & Moncharmontia apenninica (DE CASTRO 1966) & $<5$ & & & & & & & & & & & & & & & & & & \\
\hline & Scandonea samnitica DE CASTRO 1971 & $<5$ & & & & & & & & & & & & & & & & & & \\
\hline & Miliolidae indet. & $>5$ & & & & & & & & & & & & & & & & & & \\
\hline & Textularidae indet. & $<5$ & & & & & & & & & & & & & & & & & & \\
\hline & Buliminidae indet. & $<5$ & & & & & & & & & & & & & & & & & & \\
\hline & Mollusk and ostracod shell fragments & - & & & & & & & & & & & & & & & & & & \\
\hline \multirow[t]{6}{*}{ II-2 } & $\begin{array}{l}\text { Thaumatoporella parvovesiculifera (RAINERI } \\
\text { 1922) }\end{array}$ & $<5$ & & & & & & & & & & & & & & & & & & \\
\hline & Aeolisaccus kotori RADOIC̈IC 1959 & $<5$ & & & & & & & & & & & & & & & & & & \\
\hline & Pseudonummuloculina heimi (BONET 1956) & $<5$ & & & & & & & & & & & & & & & & & & \\
\hline & Archaeoglobigerina sp. & $<5$ & & & & & & & & & & & & & & & & & & \\
\hline & Miliolidae indet. & $>5$ & & & & & & & & & & & & & & & & & & \\
\hline & Mollusk and ostracod shell fragments & - & & & & & & & & & & & & & & & & & & \\
\hline \multirow[t]{6}{*}{ II-3 } & $\begin{array}{l}\text { Thaumatoporella parvovesiculifera (RAINERI } \\
\text { 1922) }\end{array}$ & $<5$ & & & & & & & & & & & & & & & & & & \\
\hline & Aeolisaccus kotori RADOIČIČ 1959 & $>20$ & & & & & & & & & & & & & & & & & & \\
\hline & Pseudocyclammina sphaeroidea GENDROT 1968 & $<5$ & & & & & & & & & & & & & & & & & & \\
\hline & Hedbergella sp. & $<5$ & & & & & & & & & & & & & & & & & & \\
\hline & Miliolidae indet. & $<5$ & & & & & & & & & & & & & & & & & & \\
\hline & Mollusk and ostracod shell fragments & - & & & & & & & & & & & & & & & & & & \\
\hline
\end{tabular}

Coniacian to the Campanian (see Table 1). This suggests an early Coniacian age for the track-bearing bed.

\section{DESCRIPTION OF THE TRACK SITE}

On the sea-shore the track-bearing surface is a $38.3 \mathrm{~m}$ long and $22.7 \mathrm{~m}$ wide, $870 \mathrm{~m}^{2}$-large area with a NNW strike of $340^{\circ}$, dipping $20^{\circ}$ to the sea (Fig. 1). The overlying limestone bed is preserved at the western and northern sides of the track-bearing layer; the underlying ones are to the south, and at the eastern side of the outcrop a vertical limestone block borders the track-bearing surface. On the surface of the track-bearing layer, large sized $(\geq 40 \mathrm{~cm})$, poorly preserved footprints can be observed (Fig. 3). The rock surface is strongly karstified and there are many cracks across the footprints. Due to the slow breaking up of the limestone surface the upper (dry land-side) and the lower (seaside) zones are quite different. Wider and deeper karstic cracks occur in the upper zone, whereas the lower zone is covered by denser but thinner and shallow cracks. Near the seaside, intensive waves and organic activity also eroded the surface. The tracks have a present depth varying between 10 and $15 \mathrm{~cm}$.

Altogether 13 subcircular footprints can be observed on the track-bearing surface (for measurements see Table 2). Although the tracks are poorly preserved and karstified we suggest that they might belong to at least three different trackways. There are rounded, oval-shaped and horseshoe-shaped footprints. The differentiation of manus or pes imprints, however, is not possible, since their original size and shape has been strongly modified. The tracks are undertracks, since the expulsion rims of the tracks together with the uppermost $1-2 \mathrm{~cm}$ layer of the original surface were already eroded. The direction of the sauropod trackways is from west to east.

The first potential trackway (A1-A4) is closest to the sea (Fig. 3A-C) and is composed of four tracks, among which the first track (track A1, Fig. 3C) is partly covered by the overlying limestone bed. A single track (B1) is present between trackway $\mathrm{A}$ and $\mathrm{C}$ and cannot be related to any of the other tracks. A second possible trackway composed of at least four tracks $(\mathrm{C} 1-\mathrm{C} 4)$ is the longest (Fig. 3D). Track C0 being just nearby $\mathrm{C} 1$ might belong to this trackway as well. A further possible track (?) is also present south of C2 but it is too poorly preserved to show more details. The last assemblage of tracks on this surface includes three large footprints (D1-D3). It cannot be ruled out that they are the continuation of the $\mathrm{C}$ trackway.

\section{DISCUSSION AND CONCLUSIONS}

\section{Karstic phenomenon or dinosaur footprints?}

Since many of these footprints are in a very poor condition, one might think that these holes are perhaps not dinosaur tracks but the results of, for instance, karstic phenomena. The following arguments, however, unambiguously suggest that these holes are not due to biologic or karstic erosion but were made by large-sized, terrestrial animals:

1. Track A1, located almost directly at the seaside, is partly filled by the overlying sediments (Fig. 3B-C), clearly 

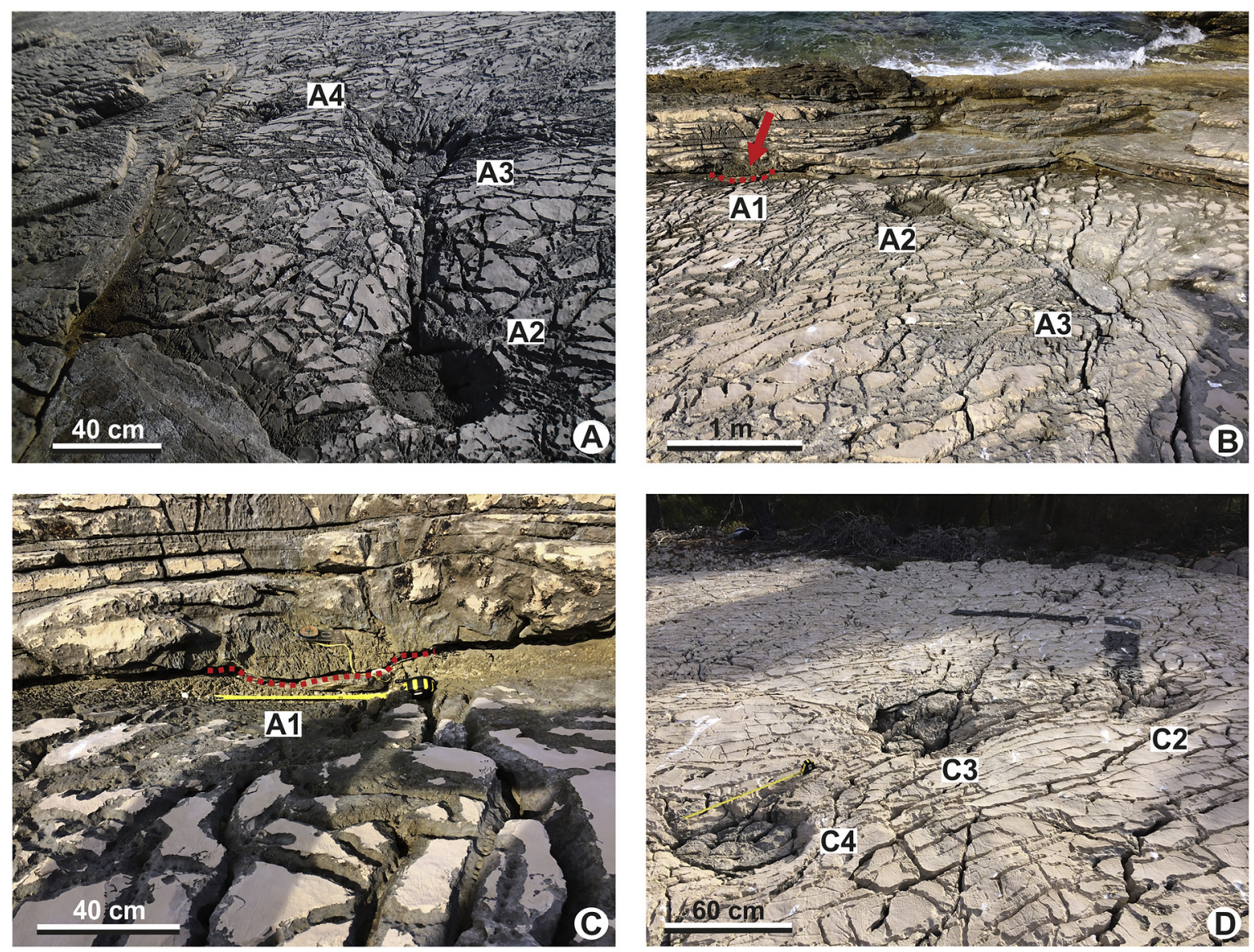

Fig. 3. Sauropod tracks on the new track-bearing beds in an Upper Cretaceous (lower Coniacian) limestone series in the northwestern part (Pelegrin) of Hvar Island. A-C, Trackway A from different angles. Note that track A1 indicated with a red dotted line is partly covered by the overlying bed. D, Eroded tracks of trackway C

indicating that the footprint is contemporaneous with the deposition of these beds.

2. The bottom of the prints is parallel with the dip of the limestone beds. If the tracks would be karstic phenomena (dissolution pan, weathering pit, etc.), their bottom

Table 2. Length measurements (in $\mathrm{cm}$ ) of 13 tracks in the track site from the Upper Cretaceous of Hvar Island, Croatia. Note that length data are only rough measurements, since the tracks are strongly karstified

\begin{tabular}{lccc}
\hline Tracks & Greatest track width & \multicolumn{2}{c}{ Pace length } \\
\hline A1 & 50 & A1-A2 & 195 \\
A2 & 56 & A2-A3 & 180 \\
A3 & 55 & A3-A4 & 190 \\
A4 & 40 & ?C0-C1 & 70 \\
B1 & 40 & C1-C2 & 320 \\
?C0 & 40 & C2-C3 & 185 \\
C1 & 55 & C3-C4 & 140 \\
C2 & 70 & D1-D2 & 120 \\
C3 & 70 & D2-D3 & 430 \\
C4 & 60 & & \\
D1 & 60 & & \\
D2 & 55 & & \\
?D3 & 80 & & \\
\hline
\end{tabular}

would be horizontal, or dipping in a different (lower) angle.

3. No karstic forms with similar shape and size can be recorded along the two km-long, 20-40 $\mathrm{m}$ wide, and ca. $60,000 \mathrm{~m}^{2}$ surface of limestone beds, from Duga Bay to Parja Bay. Only a few root-karst holes are present in certain parts of the limestone bed.

4. In some cases (e.g., $\mathrm{A} 1-\mathrm{A} 2-\mathrm{A} 3-\mathrm{A} 4)$ the similar, periodic distances between the tracks on the same limestone surface further support the "track-bearing bed" hypothesis.

\section{Comparison of the tracks}

The large-sized, circular to oval-shaped footprints from the new site of Hvar suggest that they were made by sauropod dinosaurs. None of the tracks show any indication of wellseparated digits, excluding an ornithischian or theropod affinity of the trackmaker (Lockley and Hunt 1995; Lockley and Meyer 2000). Since the preservation of the tracks is extremely poor, only some very basic comparisons can be presented here. Track D3 slightly resembles the pes imprint of an Albian track from the Solaris site, Istria (Dalla Vecchia and Tarlao 2001, Fig. 7), although there is no indication of the fingers on the Hvar track. The general shape, size and 
gauge of the tracks appear to be similar to the pes imprints of the Cenomanian Carigador/Karigador site of Istria, though the pace length is larger in the Hvar trackways (compare e.g., trackway A to that of Dalla Vecchia et al. 2001, Text-Fig. 8), suggesting slightly higher speed of these animals. Since all the footprints are very close to the supposed trackway midline in all the three possible trackways (A, C, D), the gauge can be interpreted as narrow (according to Farlow et al. 1989 and Lockley et al. 1994), similar to that of the Albian (Dalla Vecchia and Tarlao 2000) and Cenomanian sauropod tracks from Istria (Dalla Vecchia et al. 2001). Compared to the sauropod tracks from Žukova beach, Hvar (Mezga et al. 2006b), the new tracks are much deeper, though this is partly due to the karstic erosion.

The track size $(>40 \mathrm{~cm})$ makes it possible to estimate the body length of the track-makers. The new footprints, according to the hip height calculation of Alexander (1989), are comparable and some of them even larger than those described by Mezga et al. (2006b), suggesting similarly largesized (ca. 15-25 m body length) animals on all the Hvar track sites.

\section{Importance of the new Hvar track sites}

The continental vertebrate record of the late Cenomanian to Campanian interval of Europe is extremely scanty and sauropod fossils are almost entirely missing from this period. The only records of these quadrupedal herbivores from this 20 myr-long gap, - all of them discovered only relatively recently -, are as follows: 1 ) a tooth from the Santonian of the Transdanubian Range, Hungary (Ösi et al. 2017) - this region was on the northern part of the Apulian Microplate during the Cretaceous (Csontos and Vörös 2004) -; 2) footprints from the Santonian of Apulia, southern Italy (Nicosia et al. 1999; Mannion and Upchurch 2011) and 3) footprints from the Turonian of the Žukova Cove, Hvar Island, Croatia (Mezga et al. 2006b) - both regions belonging to the ADCP.

The new sauropod footprint record from the mid-Late Cretaceous of Hvar Island extends our knowledge concerning Late Cretaceous sauropods from this critical period. The new site with its early Coniacian age represents a stratigraphic level similar or slightly younger than that of the Žukova Bay tracks, suggesting that the occurrence of sauropod dinosaurs, at least in the eastern part of the European Cretaceous archipelago, was not accidental but could have been periodical (perhaps seasonal) and much more common than previously thought.

The Apulian microplate, including the ADCP and some islands (e.g., the Transdanubian Range during the Santonian; Haas 2001), or the Turonian to Campanian islands of the Northern Calcareous Alps (Wagreich and Faupl 1994; Ösi et al. 2019), might have functioned as transit areas for faunal interchanges between southern (i.e., Africa) and northern (i.e., stable Europe) landmasses (Dalla Vecchia 2002; Pereda-Suberbiola 2009; Csiki-Sava et al. 2015). This hypothesis is supported by increasing evidence from faunal similarities between Cretaceous Gondwanan and European localities (e.g., Buffetaut 1989; Pereda-Suberbiola 2009; Zarcone et al. 2010; Rabi and Sebők 2015; Csiki-Sava et al. 2015; Fanti et al. 2015; Dal Sasso et al. 2016; Sallam et al. 2018; Holwerda et al. 2018). Hopefully, with further systematic fieldwork, more interesting dinosaur track sites will come to light from the Cretaceous series of Dalmatia and probably in other parts of the ADCP as well.

\section{ACKNOWLEDGMENTS}

We are thankful to Aleksandar Mezga (Department of Geology and Paleontology, Faculty of Science, University of Zagreb) for his important reflections and observations. Grateful thanks go to Ágnes Siegl-Farkas, palynologist, for palynological analysis and for the laboratory work of Istvánné Bátori (Mining and Geological Survey of Hungary), also many thanks to Nikolett Sipka (MOL Laboratory, Budapest) for her accurate work. Attila Ösi thanks the Dinosaur Research Group of the Eötvös University and NKFIH OTKA (Grant No. K116665) for financial support. Viviána Jó is thanked for fieldwork assistance and help in preparation of the figures, and János Magyar for his technical help. We thank the two anonymous reviewers for the constructive comments that highly improved the manuscript.

\section{REFERENCES}

Alexander, R.McN. (1989). Dynamics of dinosaurs and other extinct giants. Columbia University Press, New York, p. 167.

Boscarolli, D. and Dalla Vecchia, F.M. (1999). The upper Hauterivian-lower Barremian dinosaur site of Bale/Vale (SW Istria, Croatia). Natura Nascosta, 18: 1-5.

Boscarolli, D., Laronica, M., Tentor, M., and Venturi, S. (1993). Prima segnalazione di resti di dinosaurio nei calcari hauterivioni di piattaforma dell' Istria meridionale (Croatia). Natura Nacosta, 7: 1-20.

Buffetaut, E. (1989). Archosaurian reptiles with Gondwanan affinities in the Upper Cretaceous of Europe. Terra Nova, 1: 6974, https://doi.org/10.1111/j.1365-3121.1989.tb00328.x.

Csiki-Sava, Z., Buffetaut, E., Ösi, A., Pereda-Suberbiola, X., and Brusatte, S.L. (2015). Island life in the Cretaceous-faunal composition, biogeography, evolution, and extinction of landliving vertebrates on the Late Cretaceous European archipelago. ZooKeys, 469: 1-161.

Csontos, L. and Vörös, A. (2004). Mesozoic plate tectonic reconstruction of the Carpathian region. Palaeogeography, Palaeoclimatology, Palaeoecology, 210(1): 1-56.

Dal Sasso, C., Pierangelini, G., Famiani, F., Cau, A., and Nicosia, U. (2016). First sauropod bones from Italy offer new insights on the radiation of Titanosauria between Africa and Europe. Cretaceous Research, 64: 88-109.

Dalla Vecchia, F.M. (1998a). Remains of Sauropoda (Reptilia, Saurischia) in the Lower Cretaceous (Upper Hauterivian/Lower Barremian) limestones of SW Istria (Croatia). Geologica Croatica, 51(2): 105-131. 
Dalla Vecchia, F.M. (1998b). Theropod footprints in the Cretaceous Adriatic-Dinaric Carbonate Platform (Italy and Croatia). Gaia, 15: 355-367.

Dalla Vecchia, F.M. (2001). A vertebra of a large Sauropod Dinosaur from the lower Cretaceous of Istria (Croatia). Natura Nacosta, 22: 14-33.

Dalla Vecchia, F.M. (2002). Cretaceous dinosaurs in the AdriaticDinaric carbonate platform (Italy and Croatia): paleoenvironmental implications and paleogeographical hypotheses. Memorie della Società Geologica Italiana, 57: 89-100.

Dalla Vecchia, F.M. (2009). Tethyshadros insularis, a new hadrosauroid dinosaur (Ornithischia) from the Upper Cretaceous of Italy. Journal of Vertebrate Paleontology, 29/4: 1100-1116.

Dalla Vecchia, F.M. and Tarlao, A. (1995). Dinosaur evidence in the Cretaceous of Istria (Croatia). In: 1. Hrvatski Geološki Kongres (First Croatian Geological Congress), Zbornik Radova (Proceedings), Zagreb, Vol. 1, pp. 151-154.

Dalla Vecchia, F.M. and Tarlao, A. (2000). New dinosaur track sites in the Albian (Early Cretaceous) of the Istrian peninsula (Croatia). Part II: Paleontology. Memorie di Scienze Geologiche, 52(2): 227-292.

Dalla Vecchia, F.M. and Tarlao, A. (2001). Atlas of the ichnofossils of the late Albian (Cretaceous) site of Solaris campground (Istria, Croatia). Part I: Tridactyl footprints. Natura Nascosta, 23: $14-23$.

Dalla Vecchia, F.M., Tunis, G., Venturini, S., and Tarlao, A. (2001). Dinosaur track sites in the upper Cenomanian (Late Cretaceous) of the Istrian Peninsula (Croatia). Bollettino della Società Paleontologica Italiana, 40(1): 25-54.

Davies, G.R. (1970). Carbonate bank sedimentation, eastern Shark Bay, Western Australia. American Association of Petroleum Geologists Memoir, 13: 85-168.

Debeljak, I., Košir, A., and Otoničar, B. (1999). A preliminary note on dinosaurs and non-dinosaurian reptiles from the upper cretaceous carbonate platform succession at Kozina (SW Slovenia). Slovenska Akademija Znanosti in Umetnosti, Ljubljana, p. 23.

Diedrich, C. (2005). Dinosaur megatracksites in Croatia on the Adriatic Carbonate Platform - stratigraphy, sedimentology and paleoenvironment of the shallow subtidal, tidal flat to sabkha in the Middle Cenomanian to the Lower Turonian of Hvar Island. Abstract, Sediment Meeting, Bern, pp. 18-20.

Diedrich, C. (2010). Dinosaur megatracksites in carbonate intertidal flats and their possible producers in the Cenomanian/ Turonian of the Northern Tethys costal migration zones between Africa and Europe. Bulletin of the Tethys Geological Society, 5: 1-21.

Diedrich, C., Caldwell, H.W., and Gingras, M. (2011). High-resolution stratigraphy and palaeoenvironments of the intertidal flats to lagoons of the Cenomanian (Upper Cretaceous) of Hvar Island, Croatia, on the Adriatic Carbonate Platform. Carbonates and Evaporites, 26(4): 381-399.

Fanti, F., Cau, A., Cantelli, L., Hassine, M., and Auditore, M. (2015). New information on Tataouinea hannibalis from the Early Cretaceous of Tunisia and implications for the tempo and mode of rebbachisaurid sauropod evolution. PLoS One, 10(4): e0123475.
Farlow, J.O., Pittman, J.G., and Hawthorne, J.M. (1989). Brontopodus birdii, Lower Cretaceous sauropod footprints from the U.S. Gulf Coastal Plain. In: Gillette, D.D. and Lockley, M.G. (Eds.), Dinosaur tracks and traces. Cambridge University Press, Cambridge, pp. 371-394.

Fio Firi, K., Bercovici, A., Shevcuk, O., and Sremac, J. (2017). Late Cretaceous palynoflora from the central part of the Adriatic Carbonate Platform (Islands of Hvar and Šćedro), southern Croatia. Cretaceous Research, 74: 142-150.

Gušić, I. and Jelaska, V. (1990). Upper Cretaceous stratigraphy of the island of Brač within the geodynamic evolution of the Adriatic Carbonate platform. Djela Jugoslavenske Akademije Znanosti i Umjetnosti, 69, 160.

Haas, J. (2001). Alpine evolutionary cycle. In: Haas, J. (Ed.), Geology of Hungary. Eötvös University Press, Budapest, pp. 1-75.

Holwerda, F.M., Díez Díaz, V., Blanco, A., Montie, R., and Reumer, J.W. (2018). Late Cretaceous sauropod tooth morphotypes may provide supporting evidence for faunal connections between North Africa and Southern Europe. PeerJ, 6: e5925, https://doi. org/10.7717/peer.5925.

Jerinić, G., Jelaska, V., and Alajbeg, A. (1994). Upper-Cretaceous organic-rich laminated limestones of the Adriatic-Dinaric Carbonate Platform, Island of Hvar, Croatia. American Association of Petroleum Geologists Bulletin, 78: 1313-1321.

Kozarić, Z., Šparica, M., and Bajraktarević, Z. (1996). Histological bone structure of Lower Cretaceous dinosaurs from southwest Istria (Croatia). Cretaceous Research, 17: 741-749.

Lockley, M.G., Farlow, J.O., and Meyer, C.A. (1994). Brontopodus and Parabrontopodus ichnogen. nov. and the significance of wide- and narrow-gauge sauropod trackways. Gaia, 10: 135146.

Lockley, M.G. and Hunt, A.P. (1995). Ceratopsid tracks and associated ichnofauna from the Laramie Formation (Upper Cretaceous: Maastrichtian) of Colorado. Journal of Vertebrate Paleontology, 15(3): 592-614.

Lockley, M.G and Meyer, C. (2000). Dinosaur tracks and other fossil footprints of Europe. Columbia University Press, New York, p. 360.

Mannion, P.D. and Upchurch, P. (2011). A re-evaluation of the 'mid-Cretaceous Sauropod hiatus' and the impact of uneven sampling of the fossil record on patterns of regional dinosaur extinction. Palaeogeography, Palaeoclimatology, Palaeoecology, 299: 529-540.

Marinčić, S. and Majcen, Ž. (1968). Osnovna geološka karta SFRJ, 1:100.000, list Jelsa K33-34 (Basic geological map of SFRY, 1: 100 000, sheet Jelsa K33-34). Institute of Geology Zagreb; Federal Geological Survey, Beograd.

Mauko, A. and Florjančič, B. (2003). Dinosaur footprints in the Upper Turonian-Coniacian limestone in the Krnica Bay. Geologija, 46(1): 93-100.

Mezga, A. and Bajraktarević, Z. (1999). Cenomanian dinosaur tracks on the islet of Fenoliga in southern Istria, Croatia. Cretaceous Research, 20(6): 735-746.

Mezga A., Tunis, G., Moro, A., Tarlao, A., Ćosović, V., and Bucković, D. (2006a). A new dinosaur tracksite in the cenomanian of Istria, Croatia. Rivista Italica Paleontographica et Startigraphica, 112(3): 435-445. 
Mezga, A., Meyer, C.A., Tešović, B.A., Bajraktarević, Z., and Gušić, I. (2006b). The first record of dinosaurs in the Dalmatian part (Croatia) of the Adriatic-Dinaric Carbonate Platform (ADCP). Cretaceous Research, 27: 735-742.

Murray, J.W. 1991). Ecology and paleoecology of benthic foraminifera. Longman Scientific \& Technical, Harlow, p. 397.

Nicosia, U., Marino, M., Mariotti, N., Muraro, C., Panigutti, S., Petti, F.M., and Sacchi, E. (1999). The Late Cretaceous dinosaur tracksite near Altamura (Bari, southern Italy). Geologica Romana, 35: 231-236.

Ösi, A., Csiki-Sava, Z., Prondvai, E. (2017). A sauropod tooth from the Santonian of Hungary and the European Late Cretaceous "Sauropod hiatus". Scientific Reports, 7(1): 1-8.

Ösi, A., Szabó, M., Kollmann, H., Wagreich, M., Kalmár, R., Makádi, L., Szentesi, Z., Summesberger, H. (2019). Vertebrate remains from the Turonian (Upper Cretaceous) Gosau Group of Gams, Austria. Cretaceous Research, 99: 190-208.

Pereda-Suberbiola, X. (2009). Biogeographical affinities of Late Cretaceous continental tetrapods of Europe: a review. Bulletin de la Société Géologique de France, 180(1): 57-71.

Premoli Silva, I. and Sliter, W.V. (2002). Practical manual of Cretaceous planktonic foraminifera. In: Premoli-Silva, I. and Rettori, R. (Eds.), International School on Planktonic Foraminifera. Dipartimento di Scienze della Terra, Università di Perugia, Perugia, p. 79.

Rabi, M., and Sebők, N. (2015). A revised Eurogondwana model: Late Cretaceous notosuchian crocodyliforms and other vertebrate taxa suggest the retention of episodic faunal links between Europe and Gondwana during most of the Cretaceous. Gondwana Research, 28(3): 1197-1211.
Sallam, H.M., Gorscak, E., O’Connor, P.M., El-Dawoudi, I.A., ElSayed, S., Saber, S., Kora, M.A., Sertich, J.J.W., Seiffert, E.R., and LamannaM.C. (2018). New Egyptian sauropod reveals Late Cretaceous dinosaur dispersal between Europe and Africa. Nature Ecology \& Evolution, 2: 445-451.

Schlagintweit, F., Kolodziej, B., and Qorri, A. (2015). Foraminiferan-calcimicrobial benthic communities from Upper Cretaceous shallow-water carbonates of Albania (Kruja Zone). Cretaceous Research, 56: 43-63.

Siegl-Farkas, Á. (2018). A Hvar szigetén talált új dinoszaurusz lábnyomos rétegsor palynológiai feltárása (Palynological results from the new dinosaur tracksite locality at Hvar Island, Croatia). Manuscript, p. 4 (in Hungarian).

Tasli, K., Özer, E., and Koç, H. (2006). Benthic foraminiferal assemblages of the Cretaceous platform carbonate succession in the Yavca area (Bolkar Mountains, S Turkey): biostratigraphy and paleoenvironments. Géobios, 39(4): 521-533.

Velič, I. (2007). Stratigraphy and paleobiogeography of Mesozoic benthic foraminifera of the Karst Dinarides (SE Europe). Geologia Croatica, 60(1): 1-113.

Wagreich, M. and Faupl, P. (1994). Palaeogeography and geodynamic evolution of the Gosau Group of the northern Calcareous Alps (Late Cretaceous, eastern Alps, Austria). Palaeogeography, Palaeoclimatology, Palaeoecology, 110(3-4): 235-254.

Zarcone, G., Petti, F.M., Cillari, A., Di Stefano, P., Guzzetta, D., Nicosia, U. (2010). A possible bridge between Adria and Africa: new palaeobiogeographic and stratigraphic constraints on the Mesozoic palaeogeography of the Central Mediterranean area. Earth-Science Reviews, 103(3-4): 154-162. 